\title{
STRUCTURAL FACTORS FOR A THIRD-GENERATION PORT: ACTIONS AND MEASURES FOR GIOIA TAURO, ITALY, IN THE REGIONAL TRANSPORT PLAN
}

\author{
FRANCESCO RUSSO ${ }^{1} \&$ GIOVANNA CHILÀ ${ }^{2}$ \\ ${ }^{1}$ Dipartimento di Ingegneria dell'Informazione, delle Infrastrutture e dell'Energia Sostenibile, \\ Università Mediterranea di Reggio Calabria, Italy \\ ${ }^{2}$ Environment and Public Works, Municipality of Motta San Giovanni, Italy
}

\begin{abstract}
The aim of this paper is to identify structural factors for the realization of a Gioia Tauro third-generation port, starting from the analysis and the goals of Calabria Regional Transport Plan (RTP). The port of Gioia Tauro has the potential to become a third-generation port in which, together with the transport functions, actions are developed to increase the added value of goods in transit. The paper examines how on the basis of the existing limits and weaknesses, actions and measures can be planned to achieve the goal of a third-generation port, summarizing the effects they produce with their implementation. The results obtained are significant because they allow you to face the decisions to be taken responsibly. The results obtained for the outcomes are presented, based on the hypothesized investments and therefore the qualitative impacts on the goals.
\end{abstract}

Keywords: regional transport plan, third-generation port, planning, maritime network, logistics systems.

\section{INTRODUCTION}

UNCTAD [1] identifies the structure factors of a generic ports and by means of these introduced the general definition of "port generation."

The notion of generation is very interesting because synthesize a large amount of specific characteristics that more complex definition cannot emerge.

In the first generation of port there are ports born next to the cities, that from more than 27 centuries allows the trade between the different population. At today the port city serves as big door to the consumption of the city.

The second generation of ports born around of half of 20th century with the big oil plant. The main characteristics is the distance to the city and the boundary to the refineries. Similar ports are the one that serve the steel factory.

The third-generation arrives following the container revolution of the last twenty years of 20th century and explain main results in the first twenty years of 21 st century.

The container revolution permits the handling of large quantity of freight of great different typologies from/to many origin/destination; with the container change the paradigm of movement of one type of freight between only one origin destination pair using only one ship [2].

This new trade asks dedicated ports. The presence of this large and multi-destination freight permits to "open" the container and to make other works, and then increasing the value added of the freight containerized. In this way the third-port generation born, as places that participate in the supply chain not only as transport node but as very producer node.

Gioia Tauro is an intercontinental Italian port located in the Calabria region that operates as a big container node where the transhipment is realized.

The Calabria Region in 2016 produced the Regional Transport Plan [3], following the main international, European and Italian guidelines [4]-[8]. 
The structure of the Plan has been built leaving from a vision defined in 4 goals: regional economic development, external and internal accessibility, sustainability. From analysis of the current scenario of Calabria, the Plan indicates 10 objectives to pursue the 4 goals, each objective translated into an action and each action is segmented in 10 measures, obtaining finally 100 measures.

Modifying the previous regional plan that do not consider the Gioia Tauro port, the new plan put the port as one of the strategic elements for the development of the region [9]-[11]. The plan recognizes the recent works on which the role of Gioia Tauro is analyzed [11]-[13] also considering the comparison with other ports [14].

It has been highlighted in the literature [1], [3] that a port is of the third generation if: 1) it has high levels of performance in all operations relating to transport; 2) allows you to operate on goods in transit, increasing their added value. The RTP reconstructs the evolution of the port of Gioia Tauro in its three economic and temporal phases: initially conceived as an industrial port, transformed into a transhipment port and today proposed as a thirdgeneration port with the modification of the added value of goods in transit.

Strategic development directions towards third-generation are proposed and based on general objectives defined in the Calabria RTP: objective 5, which concerns the logistics system and the port system; objective 6 , which concerns the core system of Gioia Tauro; objective 7 , which concern network integrations. Finally, objective 9 concerns specific measures to improve safety and security in ports. Then, Gioia Tauro macronode can be represented as the system of relationships represented in Fig. 1, which consider the mentioned objectives.

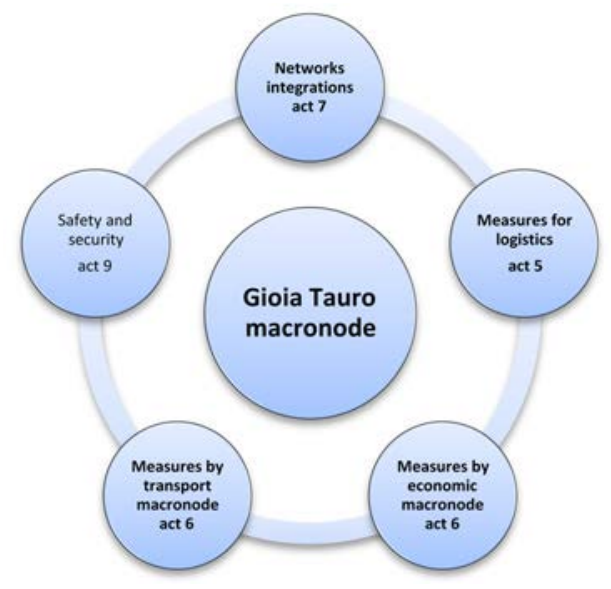

Figure 1: Macronode and related actions in RTP.

Leaving from these analyses the plan studies the current state, the limits and the weakness of the port to become a third-generation port [15]. The focal point of these paper is to recognize the actions and the measures and then the linked interventions, that permit to develop the new activities that produce added values in the main sector for which the port is vacated: general logistics [16], agri-food logistics [17], mechanical and automotive [18]. It is important to note that the port of Gioia Tauro has two important assets in the structure of the near territory that don't have a large city but only small town [19] and in the presence of a university research centre on transportation [20]. 
This paper answers the question relating to the main interventions that must be carried out to allow the potential of the third generation to be developed. The methodology used in the plan is to operate in some subsequent steps, based on the analyses carried out on the existing limits [15]. The first step is to translate general goals into specific objectives, and these into actions. Actions are specified in measures, and each measure in interventions.

On this basis, Section 2 reports the actions and measures necessary to reach a thirdgeneration port. Actions and measures are, in the paper, discussed in a different way from the plan, in order to highlight the measures that refer to the increase in transport performance (a) and those that refer to the increase in value added in freight in transit (b). Based on the general measures, in Section 3, the main interventions defined by the plan are recalled, again aggregated into interventions for the enhancement of transport and interventions for added value. For the different sets of interventions, the potential effects on port operations are presented with quantitative references. Finally, Section 4 summarizes the expected results for the port, highlighting that the methodology followed, up to the definition of the measures, can also be used in other ports that aim to become third generation ports.

\section{MEASURES TO BECOME A THIRD-GENERATION PORT}

\subsection{Measures to increase transport performance}

Starting from the limits and weaknesses that prevent the achievement of high performance, two groups of measures are identified. A first group is related to measures that address the "internal" limits of the port $(6.6,6.7,6.8)$. A second group addresses the limits connected to integration into the TEN-T core network (7.1), in this group there are measures relating to the construction of infrastructures and others relating to interactions with the EU for changes in future EU plans, of the role of these infrastructures.

Measure 6.6 provides support for the development of maritime transport activities:

- Transhipment development.

- Activation of a PCS (Port Community System) that integrates the economic activities of the port, on the basis of the most widespread PCS, in line with the indications of the Minister of Transport.

- Extension of the PCS to the entire industrial bordering area, and measures for the extension of the unified services of the PCS to other activities.

- Promotion of lo-lo maritime connections.

- Promotion of national and international ro-ro connections and connections to the railway network.

- Promotion of motorways of the sea, European in the context of TEN-T, and Mediterranean in the context of TMN-T.

- Support for the attraction of traditional intercontinental traffic with final destination Calabria and Southern Italy.

- Full and immediate use of national and/or EU incentives for combined road/sea transport (Ecobonus).

Measure 6.7 provides support for the development of railway transport - Gateway - and road transport activities:

- Activation of an international railway gateway in terms of infrastructure and in terms of services. 
- Full and immediate use of national incentives for combined road/rail transport (Ferrobonus).

- Promotion of customs corridors and fast corridors towards the large national logistic hubs with informative integration of the various logistic subjects involved in the fast corridor.

- Measures for the integrated construction with the freight village of a support area for road transport with adequate truck services.

Measure 6.8 provides support for the development of the integration of transport activities with node infrastructural interventions:

- Extension of the special mobility areas of the port area to the industrial bordering areas.

- Extraordinary maintenance interventions on port and industrial area road infrastructures.

- Interventions to extend the area covered by the types of port security to the industrial areas, enhancement of the security infrastructures.

- Interventions relating to the upgrading of the port.

- Interventions related to the interaction with terrestrial networks.

According to the RTP, it's necessary to carried out measures related to 7.1 Infrastructures of EU and national interest. The infrastructures envisaged in the European TEN-T Plan (PTENT-T), in the National Strategic Plan for Ports and Logistics (PSNPL), National Airport Plan (PNA), are invariant infrastructures for the Regional Transport Plan of Calabria starting from the Master Plan. It is necessary to:

- Progress of the design and construction phases of the infrastructures defined within the European TEN-T networks of core and comprehensive level, and of the infrastructures provided for in the PSNPL and in the PNA.

- Monitoring, by the Region through the established Autonomous Organizational Unit "Regional Transport Plan," of the development of the European TEN-T 5 corridor. Develop a strong presence of the Region in the tables of supranational choices of the government of the large flows of goods and people (TEN-T and TMN-T networks, Motorways of the Sea, Rail Freight Corridor, Corridor Forum, etc.).

- Promote an interlocution with the EU Commission and the Ministry of Transport for the purpose of: a) inserting the Jonica State Road 106, south section from Catanzaro Lido until reunification with the Mediterranean Motorway, in the European TEN-T comprehensive network, this section constitutes an invariant infrastructure for the Regional Plan of Transportation; b) inserting the Ionian railway line in the European TEN-T comprehensive network, this section constitutes an invariant infrastructure for the Regional Transport Plan; c) upgrading to module 1000 and gauge PC80 of the Paola - Cosenza - Sibari railway section, this section constitutes an invariant infrastructure for the Regional Transport Plan; and d) inserting the Lamezia airport node in the TEN T core network, in relation to the indications of the National Airport Plan.

- Realize a feasibility report for the Salerno - Battipaglia - Reggio Calabria railway line with high speed characteristics and lean technical specifications, extendable to width.

- Develop the theme of the Euro-Mediterranean Transport Plan (PTMN-T).

\subsection{Measures to increase value added in freight in transit}

The measures necessary for the development of activities that make it possible to increase the added value of goods (all or part of them) in transit are more complex [3]. The starting 
point is always given by the limits and weaknesses previously studied [15], but three groups of measures are identified.

A first group relates to the measures that address the direct limits for the development of the three sectors $(5.2,5.3,5.4)$, identifying those specific to each sector. A second group addresses the overall problems that the node must solve in order to become a production node of added value both for specific sectors and for any other established sector $(6.1,6.2,6.3$, $6.4,6.5)$. A third group concerns immaterial measures transversal to the increase of productivity in transport and of added value in goods. This group includes measures for research (6.9), for the definition of a brand (6.10) and for the reduction of risks (9.7).

In relation to the measure 5.2 (general logistics [16]), it's necessary to:

- Specify an action plan for external logistics, considering current situation with platforms of various types and sizes, public, private or mixed.

- Prepare the design and then construction of the infrastructural works relating to the logistic nodes based on the results of the reports or feasibility studies, specifying the terms of management and the economic useful lifetimes.

- Specify the sector plan for reverse logistics, both for industrial agglomerations and for urban areas. The plan can be developed as part of the general external logistics plan or have its own specific elaboration in line with that for general logistics.

- Prepare the design and then construction of the infrastructural works relating to the logistic nodes on the basis of the results of the feasibility studies, specifying the terms of the (private) management and the economic useful lifetimes.

- Apply the intelligent strategy, linking the logistics strategy with that of ICT; develop in particular the interaction in the field of reverse.

The infrastructural invariants to support logistics are defined within the former industrial areas. Road or rail interventions within the node are also considered. It is necessary to realize:

- modernization and extraordinary maintenance of existing infrastructures;

- interventions for the connections between the industrial area and the main railway, port and airport transport nodes; and

- upgrading of railway nodes in order to support intermodal transport in industrial area or in neighbouring industrial areas.

In relation to the measure 5.3 (agri-food logistics [17]), it's necessary to:

- Specify the action plan for external agri-food logistics. The plan can be developed as part of the general external logistics plan or have its own specific elaboration in line with that for general logistics, considering the current situation with platforms of various types and sizes, public, private or mixed, must consider the production processes of the production chains: vine, olive, citrus, vegetable. The plan must consider the potential of agri-food related to different territorial segments of production and to different territorial market segments.

- Consider the potential of the Gioia Tauro node which includes the potential of the international market, starting with the best productions already present in the region known in the most important international markets, such as that of tuna.

- Apply the intelligent strategy, linking the logistics strategy with that of ICT and on the other with that of agri-food.

In relation to the measure 5.4, it's necessary to specify the action plan for external mechanical and automotive logistics [18]. The plan can be developed as part of the general 
external logistics plan or have its own specific elaboration in line with the one for general logistics, considering the current situation with company platforms of various types and sizes, it must consider the production processes considering the size of the production plants.

According to the RTP [3], it's necessary to carried out measures by economic node related to: Free Zone, Special Economic Zone, Special Territorial Zone; Integrated Logistics Area; Support for the development of productive activities; Simplification, Security, Streamlining and Scouting; Integration of operational subjects.

Measure 6.1 provides: Promotion of the Free zone, inside the port, not fully used to date; Establishment of a Special Zone that integrates the Port Areas with those of the boundary industrial area, with a specific regulation of the Special Economic Zone, with measures on taxation, unitary governance and international promotion.

Measure 6.2 provides the establishment of the ALI, in the dual role of quality interlocutor of the system and subject entitled to the promotion of integrated development interventions, which can also be implemented through co-financing mechanisms on structural funds, for which the Region in one of the Port Authority of Gioia Tauro (or the Port System Authority to be established) is the lead promoter.

Measure 6.3 provides the activation of specific lines of intervention to support economic activities in the international agri-food, engineering, manufacturing and energy sectors.

Measure 6.4 provides: Activation of the one-stop shop for economic activities on the basis of the convergence of administrative processes relating to the start-up of economic activities and directly related aspects of services; Simplification of the approval procedures for infrastructure projects; One stop shop: establishment of a single service (body) responsible for carrying out port services, which will act in coordination with the Port Authority; Transposition of directives for integration and simplification of procedures from international agreements; Measures for the transformation of all internal processes in the area affected by the port and the areas bordering to the port into lean-type processes, which can be extended to a greater extent, where the technical and legislative characteristics are more practicable.

Measure 6.5 provides: Measures for the institutional and operational integration of the actions of the SEZ with those of the ALI, and integration with the Port Authority actions; Definition of a single governance of the processes.

According to the RTP [2], the last set refers to immaterial measures related to the increase of productivity in transport and of added value in goods.

In relation to measure 6.9 Research and operational applications, it is necessary to activate a research centre on transport and logistics, with main operational applications concerning the port and the industrial area with research activities in transport and logistics to support the main sectors established: agri-food, external logistics, manufacturing with particular reference to the mechanical and automotive, energy, ICT. It is also necessary to create an Innovation campus, starting from the best available experiences, for the recovery of degraded areas, in a general approach of sustainability, to promote start-ups and spin-offs connected to the Research Center, to the university system of Calabria [20].

In relation to measure 6.10 Gioia Tauro System Brand, it is necessary to promote a brand linked to the port and the industrial area of Gioia Tauro, with definition of names, related characteristics of memorization, recognition, translatability, references to the overall image of the area and specific characteristics, distinction from competing ports, and where possible and necessary legally registered.

Finally, in relation to measure 9.7, Reduction of risks associated with security in port infrastructures, it is necessary to prepare the Risk Reduction Plan in Ports in line with the provisions of the CISM (International Committee for Maritime Security in Ports), which has the task of drawing up a national program against terrorist acts aimed at the Maritime sector 
and establishing the level of security according to as established by the IMO (International Maritime Organization). The Plan must consider, in addition to the indications provided by the CISM, the combinations of greater probability of occurrence due to vulnerability and exposure in "as is" conditions, envisaging interventions for the "to be" condition, identifying the priorities for intervention based on the cost of the time of realization and associated risk reduction.

\section{INFRASTUCTURAL INTERVENTIONS}

The definition of the interventions derives directly from the proposed measures. The interventions, as well as the generating measures, are of various types, according to whether one passes from structural interventions, and therefore of a strategic level, to interventions in the services and therefore of a tactical or operational level. This section refers to the strategic level interventions on infrastructures because they have a directly monetizable cost. The interventions foreseen for the services are not mentioned because, in fact, interventions not of a structural nature, such as the "ferrobonus," which exhaust their effects with the exhaustion of the subsidies supplied with them. Strategic interventions of a legal nature such as those relating to simplification are not even mentioned because they deal with problems of a general nature and therefore transversal to all ports.

Attention is therefore placed on infrastructural interventions. For continuity and congruence with the proposed approach, they are divided into groups relating to: increasing in transport performance and increasing in added value. It should be noted that the first interventions reduce disutility and therefore are in any case perceived by users as costs, while the latter increase the value and therefore the utility of the goods.

The optimal situation of a third-generation port is one in which:

$$
\text { costs (generalized from transport) < benefits (added value). }
$$

Interventions proposed are reported in Tables 1 and 2. The material interventions are classified in the RTP in invariant or executable: invariant are defined the infrastructural works that can already be prefigured and which are characterized by obligatory actions that in any case should be undertaken; executable are defined as infrastructural works that can already be envisaged as aimed at improving the efficiency and effectiveness of the transport system. The interventions are in turn divided into realistic and mature or programmatic, according to the fulfilment of the requisites required by the ex-ante conditionality, foreseen for the use of the structural European funds. Realistic and mature invariant interventions are consistent with the objectives of the RTP and the pursuit of the targets of the RTP, are immediately feasible, equipped with a roadmap and budget framework with resources available to be implemented by 2023 , meet the legal requirements for an environmental and strategic assessment.

Table 1 includes the main interventions planned to improve the transport component. The interventions are divided into two groups: interventions relating to port and interventions relating to railway. As regards the port, in addition to some interventions that need to maintain the quality of the service of the existing quays and yards, interventions that tend to resolve capacity constraints can be detected and can be summarized in: 1) dredging of the existing quay to bring the entire extension to $18 \mathrm{~m} ; 2$ ) creating a new quay on the west side to allow ships to stop for storage operations; and 3) create a new 500-m quay on the south side to solve the capacity constraints of the port which has all the quays occupied with multiyear concessions and cannot accommodate other companies. 
Table 1: Main interventions planned to improve transport components.

\begin{tabular}{|c|c|c|c|c|c|}
\hline $\begin{array}{l}\text { Transport } \\
\text { mode }\end{array}$ & \multicolumn{2}{|r|}{ Intervention } & $\begin{array}{c}\text { Budget } \\
\text { framework } \\
(\mathrm{mln} €)\end{array}$ & $\begin{array}{l}\text { Invariant/ } \\
\text { Executable } \\
\quad(\mathrm{I} / \mathrm{E})\end{array}$ & $\begin{array}{c}\text { Realistic } \\
\text { and mature/ } \\
\text { programmatic } \\
(\mathrm{RM} / \mathrm{P})\end{array}$ \\
\hline \multirow{8}{*}{ 苛 } & 1 & Dry dock - Industrial facilities & 40.00 & $\mathrm{I}$ & $\mathrm{RM}$ \\
\hline & 2 & Dry dock - Civil works & 20.00 & $\mathrm{I}$ & $\mathrm{RM}$ \\
\hline & 3 & $\begin{array}{l}\text { Completion of the works relating to the west } \\
\text { quay }\end{array}$ & 15.00 & I & $\mathrm{RM}$ \\
\hline & 4 & $\begin{array}{l}\text { Railway gateway - New intermodal terminal of } \\
\text { the Port of Gioia Tauro }\end{array}$ & 20.00 & I & $\mathrm{RM}$ \\
\hline & 6 & $\begin{array}{l}\text { Adaptation of the existing northern quay section } \\
\text { to the new northern quay sections in the } \\
\text { execution phase and relative deepening of the } \\
\text { seabed }\end{array}$ & 5.50 & I & $\mathrm{RM}$ \\
\hline & 7 & $\begin{array}{l}\text { Deepening and consolidation works of the } \\
\text { seabed of the port channel, structural adjustment } \\
\text { of the eastern quay elements of section "D" and } \\
\text { construction of the third runway }\end{array}$ & 5.50 & I & $\mathrm{RM}$ \\
\hline & 8 & $\begin{array}{l}\text { Regularization works of the seabed of the } \\
\text { southern evolution basin and of the port channel } \\
\text { - Port of Gioia Tauro }\end{array}$ & 1.30 & I & $\mathrm{RM}$ \\
\hline & 9 & $\begin{array}{l}\text { Development of the quay of the southern } \\
\text { evolution circle, for the potential establishment } \\
\text { of other transhipment and/or ro-ro activities }\end{array}$ & 30.00 & I & $\mathrm{RM}$ \\
\hline \multirow{7}{*}{ 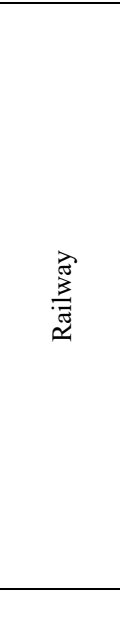 } & 4 & $\begin{array}{l}\text { Railway gateway - New intermodal terminal of } \\
\text { the Port of Gioia Tauro }\end{array}$ & 20.00 & I & $\mathrm{RM}$ \\
\hline & 15 & $\begin{array}{l}\text { Strengthening of the multimodal north } \\
\text { connection to the TEN-T railway and motorway } \\
\text { networks }\end{array}$ & 5.00 & I & $\mathrm{RM}$ \\
\hline & 16 & $\begin{array}{l}\text { Second track electrification and upgrade to } 750 \\
\mathrm{~m} \text { target }\end{array}$ & 11.00 & I & $\mathrm{RM}$ \\
\hline & 17 & $\begin{array}{l}\text { Construction of the south multimodal link (Gioia } \\
\text { Tauro) to the TEN-T railway and motorway } \\
\text { networks }\end{array}$ & 1.00 & I & $\mathrm{RM}$ \\
\hline & 22 & $\begin{array}{l}\text { RFI completion of APQ } 2010 \text { interventions (also } \\
\text { reported for the railway network) }\end{array}$ & 31.50 & I & $\mathrm{RM}$ \\
\hline & 23 & $\begin{array}{l}\text { RF/02 - Gioia Tauro - Taranto - Bari railway } \\
\text { connection. Adaptation of the Tyrrhenian railway } \\
\text { line Battipaglia Reggio Calabria. Construction of } \\
\text { the new SSE (Under Electric Station) in } \\
\text { ViboPizzo and upgrading of the SSE of } \\
\text { Sambiase (also reported for the railway network) }\end{array}$ & 153.00 & I & $\mathrm{RM}$ \\
\hline & & Total cost & 434.20 & $\mathrm{I}$ & $\mathrm{RM}$ \\
\hline
\end{tabular}

These interventions make it possible to increase the transhipment capacity of the port by at least $1,000,000$ of containers or that of long-distance roro for at least 100,000 cars or 200,000 trucks and articulated lorries for short-term ferries. As regards the railway, there are a series of interventions that aim to allow the formation of European-length trains of $750 \mathrm{~m}$. Note that the cost of a path time slot is substantially independent of the train length. Hence the request for "long" trains. One of the current constraints on the expansion of rail transport is precisely the length of the trains that can be formed in the port station and that can be routed online.

The current maximum length is $500 \mathrm{~m}$, passing to $750 \mathrm{~m}$ trains, the cost is reduced by at least $33 \%$ for the user, with an advantage for the operator given by reducing, in turn, the occupation of the network, of a third, thus increasing the free slot for other services. 
Table 2: Main interventions planned to improve transport components.

\begin{tabular}{|c|c|c|c|c|c|}
\hline Transport & & Intervention & $\begin{array}{l}\text { Budget } \\
\text { framework }\end{array}$ & $\begin{array}{l}\text { Invariant/ } \\
\text { Executable }\end{array}$ & $\begin{array}{c}\text { Realistic } \\
\text { and mature/ }\end{array}$ \\
\hline & 1 & Dry dock - Industrial facilities & 40.00 & $\mathrm{I}$ & RM \\
\hline & 2 & Dry dock - Civil works & 20.00 & $\mathrm{I}$ & RM \\
\hline & 3 & $\begin{array}{l}\text { Completion of the works relating to the west } \\
\text { quay }\end{array}$ & 15.00 & I & RM \\
\hline & 4 & $\begin{array}{l}\text { Railway gateway - New intermodal terminal of } \\
\text { the Port of Gioia Tauro }\end{array}$ & 20.00 & I & RM \\
\hline$\rightleftarrows$ & 6 & $\begin{array}{l}\text { Adaptation of the existing northern quay section } \\
\text { to the new northern quay sections in the } \\
\text { execution phase and relative deepening of the } \\
\text { seabed }\end{array}$ & 5.50 & I & $\mathrm{RM}$ \\
\hline ح & 7 & $\begin{array}{l}\text { Deepening and consolidation works of the } \\
\text { seabed of the port channel, structural adjustment } \\
\text { of the eastern quay elements of section "D" and } \\
\text { construction of the third runway }\end{array}$ & 5.50 & I & RM \\
\hline & 8 & $\begin{array}{l}\text { Regularization works of the seabed of the } \\
\text { southern evolution basin and of the port channel } \\
\text { - Port of Gioia Tauro }\end{array}$ & 1.30 & I & RM \\
\hline & 9 & $\begin{array}{l}\text { Development of the quay of the southern } \\
\text { evolution circle, for the potential establishment } \\
\text { of other transhipment and/or ro-ro activities }\end{array}$ & 30.00 & I & $\mathrm{RM}$ \\
\hline & 4 & $\begin{array}{l}\text { Railway gateway - New intermodal terminal of } \\
\text { the Port of Gioia Tauro }\end{array}$ & 20.00 & I & RM \\
\hline & 15 & $\begin{array}{l}\text { Strengthening of the multimodal north } \\
\text { connection to the TEN-T railway and motorway } \\
\text { networks }\end{array}$ & 5.00 & I & RM \\
\hline & 16 & $\begin{array}{l}\text { Second track electrification and upgrade to } 750 \\
\mathrm{~m} \text { target }\end{array}$ & 11.00 & I & $\mathrm{RM}$ \\
\hline 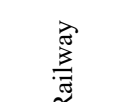 & 17 & $\begin{array}{l}\text { Construction of the south multimodal link (Gioia } \\
\text { Tauro) to the TEN-T railway and motorway } \\
\text { networks }\end{array}$ & 1.00 & I & $\mathrm{RM}$ \\
\hline & 22 & $\begin{array}{l}\text { RFI completion of APQ } 2010 \text { interventions (also } \\
\text { reported for the railway network) }\end{array}$ & 31.50 & I & RM \\
\hline & 23 & $\begin{array}{l}\text { RF/02 - Gioia Tauro - Taranto - Bari railway } \\
\text { connection. Adaptation of the Tyrrhenian railway } \\
\text { line Battipaglia Reggio Calabria. Construction of } \\
\text { the new SSE (Under Electric Station) in } \\
\text { ViboPizzo and upgrading of the SSE of } \\
\text { Sambiase (also reported for the railway network) }\end{array}$ & 153.00 & I & RM \\
\hline & & Total cost & 434.20 & I & RM \\
\hline
\end{tabular}

Table 2 shows the main interventions planned to improve the component defined as "increase in added value." The interventions are divided into three groups in relation to the three economic sectors of reference.

As regards the works relating to the agri-food sector, a series of interventions are planned that aim to reorganize an industrial area specifically identified with reorganization of the road and railway network and with the commissioning of security systems. The decisive intervention, to allow the development of the sector, is the creation of the cold pole, this in relation to what happens in the other European ports that operate in the agri-food sector.

The planned interventions regard two refrigerated warehouses (of approximately 10,000 square meters each) for rail-road and two refrigerated warehouses (also of approximately 10,000 square meters each) for all-road transport. 
Considering that to store 10,000 pallets on five levels, about 5,000 m are needed. With the planned infrastructures, there is a capacity of 40,000 pallets for the rail-road connected warehouses and a similar capacity for the all-road warehouses.

As regards the works relating to the mechanical and automotive sectors, interventions are planned to reorganize the dedicated industrial area with interventions to update the road network and security systems. The basic intervention to allow the development of the automotive sector is the construction of the Multi-floor terminal for cars, this in relation to what happens in the other European ports operating in the automotive sector, such as Zeebrugge. The intervention that allows to connect the various companies operating in the mechanical sector in the area is the creation of a Light mechanical platform. Both are in the phase of the feasibility study and then don't reported.

As far as the works relating to general logistics are concerned, most of the interventions are shared with those for the enhancement of transport previously seen. Therefore, reorganization of the areas within the port are planned with interventions for the rationalization of the road and railway network and interventions on the port yards, all directly connected to those described above. An interesting intervention is that relating to the dry dock which, however, can be considered shared with the mechanical logistics sector, and more in general with "transport port" component.

All the interventions presented are currently being financed through different national and community programs.

\section{CONCLUSIONS}

In this paper has been presented the main measures defined in RTP [3] to transform the port of Gioia Tauro in a third-generation port. The analysis leaves from the limits and weakness presented in [15], with the idea of pursuit 4 general goals. The paper presents planned measures and then the linked interventions.

A first conclusion regard how the planned measures are compliant to the goals. The degree of incidence of each measure related to port with respect to the general objectives of the Vision of RTP [3] is proposed in Table 3. From there it emerges that SE (economic development) is pursuit by all measure, followed by AE (external accessibility), the ESA (sustainability) is not directly correlated and AI (internal accessibility), as evident, is not compliant with the intercontinental port.

The main conclusions regard the methodologies and the obtained results. From a methodological point of view, and therefore applicable to other contexts, it is valid to separate the interventions, defining a group to improve the "transport" and a group for the "added value," and then separate each group into the individual component sectors. This method allows to identify the costs of each group of interventions and to evaluate their aggregate benefits. The quantitative obtained results are particularly significant, even if they obviously constitute only the result of a simulation. A direct link is presented between the planned interventions and the expected results. It is noted that in some cases the costs can, in fact, be recovered in a very short time, as for the interventions relating to the length of the trains, constituting examples of win-win interventions. Similarly, the interventions in the port allow to increase the capacity by about $20 \%$, eliminating the saturation that characterizes the port in the current conditions. The interventions in the agri-food logistics, mechanical automotive, and general logistics sectors create conditions for expansion of the production areas on the basis of the identified territorial vocations. 
Table 3: Main interventions planned to improve added value.

\begin{tabular}{|c|c|c|c|c|}
\hline Sector & Intervention & $\begin{array}{l}\text { Budget } \\
\text { framework } \\
{[\mathrm{mln} €]}\end{array}$ & $\begin{array}{c}\text { Invariant/ } \\
\text { Executable } \\
\quad(\mathrm{I} / \mathrm{E})\end{array}$ & $\begin{array}{c}\text { Realistic } \\
\text { and mature/ } \\
\text { programmatic } \\
(\mathrm{RM} / \mathrm{P})\end{array}$ \\
\hline \multirow{7}{*}{ 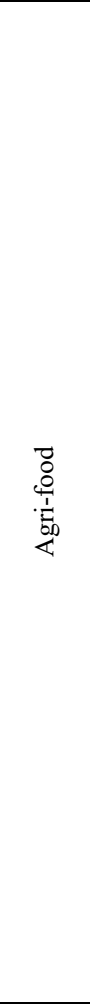 } & $\begin{array}{l}\text { Interventions to extend the area } \\
\text { covered by the types of port security } \\
\text { to the rear-port areas, enhancement of } \\
\text { security infrastructures, considering } \\
\text { the best innovations available, } \\
\text { starting from } 24 \text {-h coverage by drones } \\
\text { - Special Area of ASI } 2 \\
\text { infrastructures }\end{array}$ & 5.00 & I & RM \\
\hline & $\begin{array}{l}\text { Cold pole - Special infrastructure } \\
\text { area }\end{array}$ & 25.00 & I & $\mathrm{RM}$ \\
\hline & $\begin{array}{l}\text { Creation of an innovation campus } \\
\text { functional to the sectors: } \\
\text { transhipment, intermodal, logistics- } \\
\text { intercontinental, energy, maintenance, } \\
\text { agri-food-intercontinental }\end{array}$ & 10.00 & I & RM \\
\hline & $\begin{array}{l}\text { "Redevelopment and adaptation of } \\
\text { existing infrastructures in the second } \\
\text { industrial area of the agglomeration } \\
\text { of Gioia Tauro - Rosarno - San } \\
\text { Ferdinando" }\end{array}$ & / & I & $\mathrm{P}$ \\
\hline & $\begin{array}{l}\text { One-stop shop for port activities to be } \\
\text { connected with SURAP GT - Special } \\
\text { Services Area }\end{array}$ & 5.00 & I & RM \\
\hline & $\begin{array}{l}\text { "Intermodal terminal serving the } 2 \text { nd } \\
\text { industrial area of the industrial } \\
\text { agglomeration of Gioia Tauro - } \\
\text { Rosarno - San Ferdinando" }\end{array}$ & / & I & $\mathrm{P}$ \\
\hline & $\begin{array}{l}\text { "Customs warehouses in the } 2 \mathrm{nd} \\
\text { industrial area of the industrial } \\
\text { agglomeration of Gioia Tauro - } \\
\text { Rosarno - San Ferdinando" }\end{array}$ & / & I & $P$ \\
\hline \multirow[b]{2}{*}{ 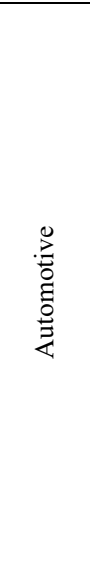 } & $\begin{array}{l}\text { Interventions for extending the area } \\
\text { covered by the types of port security } \\
\text { to the rear-port areas, upgrading of } \\
\text { security infrastructures, considering } \\
\text { the best innovations available, } \\
\text { starting from } 24 \text {-h coverage by drones } \\
\text { - Special Area ASI } 1 \text { infrastructures }\end{array}$ & 4.00 & I & RM \\
\hline & $\begin{array}{l}\text { Extension of the special mobility } \\
\text { areas of the port area to the ASIREG } \\
\text { areas, with separation of the routes } \\
\text { underlying the highway code as } \\
\text { regards dimensions, shapes, vehicle } \\
\text { registrations, etc. Creation of direct } \\
\text { connections between the area of } \\
\text { competence of the PA and the rear } \\
\text { port by extending the special roads to } \\
\text { the maximum - ASI } 1 \text { infrastructure } \\
\text { special area }\end{array}$ & 5.00 & I & RM \\
\hline
\end{tabular}


Table 3: Continued

\begin{tabular}{|c|c|c|c|c|}
\hline Sector & Intervention & $\begin{array}{l}\text { Budget } \\
\text { framework } \\
{[\mathrm{mln} €]}\end{array}$ & $\begin{array}{c}\text { Invariant/ } \\
\text { Executable } \\
\quad(\mathrm{I} / \mathrm{E})\end{array}$ & $\begin{array}{c}\text { Realistic } \\
\text { and mature/ } \\
\text { programmatic } \\
(\mathrm{RM} / \mathrm{P})\end{array}$ \\
\hline \multirow{6}{*}{ 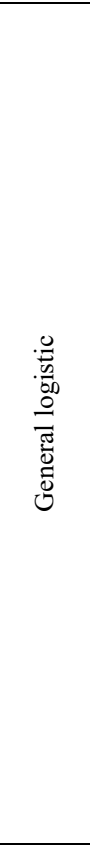 } & $\begin{array}{l}\text { Completion of viability in the North } \\
\text { area }\end{array}$ & 17.00 & I & RM \\
\hline & $\begin{array}{l}\text { Strengthening of railway and road } \\
\text { structures in industrial development } \\
\text { areas - Extraordinary maintenance } \\
\text { interventions on road and railway port } \\
\text { infrastructures: A3 Rosarno junction, } \\
\text { east side port passage }\end{array}$ & 5.00 & I & RM \\
\hline & $\begin{array}{l}\text { Strengthening of railway and road } \\
\text { structures in industrial development } \\
\text { areas - Extraordinary maintenance } \\
\text { interventions on road and railway port } \\
\text { infrastructures: equipped axis }\end{array}$ & 14.40 & I & $\mathrm{RM}$ \\
\hline & $\begin{array}{l}\text { Extraordinary maintenance } \\
\text { interventions on road and industrial } \\
\text { area port infrastructures }\end{array}$ & / & I & $\mathrm{P}$ \\
\hline & $\begin{array}{l}\text { Industrial activities to support } \\
\text { transhipment, such as container } \\
\text { maintenance workshops }\end{array}$ & / & I & $\mathrm{P}$ \\
\hline & $\begin{array}{l}\text { Development of LNG fuel bunkering } \\
\text { and refueling systems in the context } \\
\text { of Directive 2014/94/EU of the } \\
\text { European Parliament and of the } \\
\text { Council of } 22 \text { October } 2014 \text { on the } \\
\text { construction of an infrastructure for } \\
\text { alternative fuels }\end{array}$ & / & I & $\mathrm{P}$ \\
\hline
\end{tabular}

Table 4: Degree of incidence of each measure related to Gioia Tauro's port.

\begin{tabular}{|c|c|c|c|c|c|}
\hline Action & Measure & SE & $\mathrm{AE}$ & $\mathrm{AI}$ & ESA \\
\hline \multirow{3}{*}{ Action 5} & 5.2 Structuring of the general external logistic network & & & & \\
\hline & 5.3 Structuring of the logistics network for agri-food & & & & \\
\hline & 5.4 Structuring of the logistics network for metalworking & & & & \\
\hline \multirow{10}{*}{ Action 6} & $\begin{array}{l}\text { 6.1 Economic Macronode, Free Zone, Special Economic Zone, Special } \\
\text { Territorial Zone }\end{array}$ & & & & \\
\hline & 6.2 Economic Macronode, Integrated Logistics Area & & & & \\
\hline & $\begin{array}{l}\text { 6.3 Economic Macronode, Support for the development of productive } \\
\text { activities, fourth generation port }\end{array}$ & & & & \\
\hline & 6.4 Economic Macronode, Simplification, Security, Streamlining and Scouting & & & & \\
\hline & 6.5 Economic Macronode, Integration of operational subjects & & & & \\
\hline & $\begin{array}{l}\text { 6.6 Macronodo Trasporti, Support for the development of maritime transport } \\
\text { activities }\end{array}$ & & & & \\
\hline & $\begin{array}{l}\text { 6.7 Macronodo Trasporti, Support for the development of railway transport - } \\
\text { Gateway - and road transport activities }\end{array}$ & & & & \\
\hline & $\begin{array}{l}6.8 \text { Transport macronode, Support for the development of the integration of } \\
\text { transport activities with node infrastructural interventions }\end{array}$ & & & & \\
\hline & 6.9 Research and operational applications & & & & \\
\hline & 6.10 Gioia Tauro System Brand & & & & \\
\hline Action 7 & $\begin{array}{l}\text { 7.1 Infrastructures of EU interest TEN-T Plan, and of national nodal interest } \\
\text { National Strategic Plan for Ports and Logistics, National Airports Plan }\end{array}$ & & & & \\
\hline Action 9 & 9.7 Reduction of risks associated with security in port infrastructures & & & & \\
\hline
\end{tabular}


The methodology followed can be applied in other ports for which the evolution towards the third generation is being studied and is therefore of interest to technical planners and researchers. The implementation of many of the interventions has started and it will therefore be possible to verify ex-post the degree of validity of the methodology and of the results.

\section{ACKNOWLEDGEMENTS}

The Plan has been developed along the regional administration directed by Mario Oliverio (2014-2020). Many stakeholder and various regional offices participated in the development of the Plan. Some part of the paper derives from plan document. The presented synthesis is affected by the authors.

\section{REFERENCES}

[1] UNCTAD Secretariat, Port Marketing and the Challenge of the Third-Generation Port, UNCTAD Secretariat, 1994.

[2] Russo, F. \& Musolino, G., Quantitative characteristics for port generations: The Italian case study. International Journal on Transport Development and Integration, 4(2), pp. 103-112, 2020. DOI: 10.2495/TDI-V4-N2-103-112.

[3] Regione Calabria, Piano Regionale dei Trasporti, Regione Calabria: Catanzaro, 2016.

[4] European Commission, White Paper on transport: Roadmap to a single European transport area - Towards a competitive and resource efficient transport system. 2011. https://ec.europa.eu/transport/sites/transport/files/themes/strategies/doc/2011_white_ paper/white-paper-illustrated-brochure_en.pdf.

[5] European Conference of Ministers of Transport, Safe \& Sustainable Transport, A Matter of Quality Assurance, ECMT, 2003.

[6] United Nations, Transforming Our World: The 2030 Agenda for Sustainable Development, 2015. https://sustainabledevelopment.un.org/content/documents/ $21252030 \% 20$ Agenda\%20for\%20Sustainable\%20Development\%20web.pdf.

[7] United Nations, Global Indicator Framework for the Sustainable Development Goals and Targets of the 2030 Agenda for Sustainable Development, 2018. https://unstats.un.org/sdgs/indicators/Global\%20Indicator\%20Framework\%20after\% 20refinement_Eng.pdf.

[8] Ministero dell'Ambiente e della Tutela del Territorio e del Mare, Strategia Nazionale per lo Sviluppo Sostenibile, 2017. https:/www.minambiente.it/sites/default/files/ archivio_immagini/Galletti/Comunicati/snsvs_ottobre2017.pdf.

[9] Piano Strategico Nazionale della Portualità e della Logistica. Elaborato dal Ministero delle Infrastrutture e dei Trasporti, Adottato con l'art. 29 comma 1 della Legge 11/11/2014, n. 164, "Conversione in legge, con modificazioni, del decreto-legge 12 settembre 2014, n. 133, recante misure urgenti per l'apertura dei cantieri, la realizzazione delle opere pubbliche, la digitalizzazione del Paese, la semplificazione burocratica, l'emergenza del dissesto idrogeologico e per la ripresa delle attività produttive" (GU n. 262 del 11 novembre 2014, Supplemento Ordinario n. 85).

[10] Ministero Infrastrutture e Trasporti, Area Logistica Integrata Del Polo Di Gioia Tauro Documento Di Sviluppo E Di Proposte, PON Infrastrutture e Reti 2014-2020, Rome, 2018.

[11] Russo, F. \& Musolino, G., Geographic factors affecting the presence of transhipment services in regional maritime container markets. Geographical Analysis, 45, pp. 90 102, 2013. 
[12] Russo, F. \& Musolino, G., Estimating demand variables of maritime container transport: An aggregate procedure for the Mediterranean area. Research in Transportation Economics, 42, pp. 38-49, 2013.

[13] Russo, F., Musolino, G. \& Assumma V., An integrated procedure to estimate demand flows of maritime container transport at international scale. International Journal of Shipping and Transport Logistics, 6(2), 2014.

[14] Russo, F. \& Rindone, C., Data envelopment analysis (DEA) for evacuation planning. WIT Transactions on Information and Communication Technologies, vol. 43, WIT Press: Southampton and Boston, pp. 455-467, 2010.

[15] Russo, F. \& Chilà, G., Structural factors for a third-generation port: Actions and measures for Gioia Tauro in the regional transport plan. WIT Transactions on the Built Environment, vol. 204, WIT Press: Southampton and Boston, accepted for publication. ISSN 1743-3509.

[16] Musolino, G. \& Chilà, G., Structural factors for a third-generation port: Planning general logistics interventions in Gioia Tauro. WIT Transactions on the Built Environment, vol. 204, WIT Press: Southampton and Boston, accepted for publication. ISSN 1743-35.

[17] Musolino, G. \& Trecozzi, M.R., Structural factors for a third-generation port: Planning interventions for agri-food logistics in Gioia Tauro. WIT Transactions on the Built Environment, vol. 204, WIT Press: Southampton and Boston, accepted for publication. ISSN 1743-3509.

[18] Musolino, G., Cartisano, A. \& Fortugno, G., Structural factors for a third-generation port: Planning interventions for mechanical logistics in Gioia Tauro. WIT Transactions on the Built Environment, vol. 204, WIT Press: Southampton and Boston, accepted for publication. ISSN 1743-3509.

[19] Russo, F., Rindone, C. \& Panuccio, P., Structural factors for a third-generation port: Between hinterland regeneration and smart town in Gioia Tauro. WIT Transactions on the Built Environment, vol. 204, WIT Press: Southampton and Boston, accepted for publication. ISSN 1743-3509.

[20] Russo, F. \& Rindone, C., Structural factors for a third-generation port: Planning interventions for research and development in Gioia Tauro TEN-T node. WIT Transactions on the Built Environment, vol. 204, WIT Press: Southampton and Boston, accepted for publication. ISSN 1743-3509. 